\title{
PELATIHAN GURU UNTUK MENINGKATKAN KETERAMPILAN BERPIKIR MURID SELAMA PEMBELAJARAN JARAK JAUH
}

\author{
Juniriang Zendrato \\ Universitas Pelita Harapan \\ juniriang.zendrato@uph.edu
}

\begin{abstract}
Abstrak
Selama penerapan pembelajaran jarak jauh, para guru SMP-SMA Dian Harapan Jakarta memiliki kesenjangan pemikiran dalam hal keterampilan berpikir murid, yaitu: 1) $61 \%$ guru berfokus untuk peningkatan ranah kognitif saja; 2) hanya $11 \%$ guru yang mengaplikasikan keterampilan berpikir tertinggi di dalam kelas; 3) hampir seluruh guru mengajar hanya sampai pada tingkat menganalisis permasalahan saja. Keterampilan berpikir tertinggi adalah metakognisi yaitu keterampilan yang menjadikan para murid problem solvers bagi masalah sehari-hari dan mampu memberikan perbaikan pada lingkungan sekitarnya. Oleh karena itu, pelatihan guru ini difokuskan pada peningkatan keterampilan berpikir murid. Dengan demikian, tujuan pelatihan ini adalah membahas berbagai praktik dan membangun komitmen guru untuk meningkatkan keterampilan berpikir murid. Pelatihan ini dilakukan selama minggu terakhir April 2021 yang diikuti oleh enam puluh delapan guru SMP-SMA di Sekolah Dian Harapan Jakarta. Adapun metode pelaksanaannya: 1) brainstorming dengan pemberian angket; 2) membaca teks dan membuat ringkasan; 3) sharing dan kerja kelompok; dan 4) evaluasi dan refleksi individu. Hasil kegiatan menunjukkan bahwa para guru: 1) termotivasi dan berkomitmen untuk merancang pembelajaran yang meningkatkan keterampilan berpikir murid; 2) menentukan accountable partner yang dapat memberikan umpan balik; dan 3) mengapresiasi pembicara dalam hal interaksi dengan peserta, cara penyampaian pesan, pemberian materi baca, dan pemberian variasi kegiatan secara daring.
\end{abstract}

Kata Kunci: keterampilan berpikir, pembelajaran jarak jauh, transformasi

\section{PENDAHULUAN}

Sekolah Dian Harapan yang berada di Jakarta Barat merupakan kampus terpadu yang terdiri dari empat unit sekolah yaitu TK, SD, SMP, dan SMA. Sekolah ini terletak di Jln. Bedugul No. 1, Daan Mogot Baru, Jakarta Barat. Masalah yang menjadi fokus perhatian dari pimpinan sekolah adalah cara meningkatkan keterampilan berpikir murid selama pembelajaran jarak jauh yang sudah berlangsung selama 1 tahun. Berdasarkan angket yang dibagikan kepada para guru SMP-SMA diperoleh hasil sebagai berikut: 1) $61 \%$ guru berfokus pada peningkatan ranah kognitif saja; 2) hanya $11 \%$ guru yang mengaplikasikan keterampilan berpikir tertinggi (merancang) di dalam kelas; 3) hampir seluruh guru mengajar hanya sampai pada tingkat menganalisis permasalahan saja.

Sistem pengajaran seperti di atas membawa para murid hanya sampai kepada keterampilan menganalisis masalah. Murid masih belum mendapat kesempatan untuk berlatih mengevaluasi situasi dan membuat berbagai keputusan serta tindakan untuk menyelesaikan semua permasalahan 
dalam hidup mereka. Hal ini dapat terlihat dari 1) kebiasaan murid yang ingin selalu kerja cepat atau instan tanpa proses berpikir yang mendalam (berpikir praktis); 2) murid kurang mampu menyelesaikan soal-soal aplikatif; 3) murid enggan untuk berpikir dan mengungkapkan pendapatnya di kelas; 4) murid hanya sampai pada level memahami saja (sekedar tahu) dan belum sampai pada tahap membuat solusi; 5) murid lebih suka menerima penjelasan guru daripada berpikir; 6) murid malas membaca, tidak teliti saat mengerjakan tugas, dan saat memahami instruksi guru; 7) murid kesulitan untuk memecahkan masalah yang memerlukan beberapa tahap; 8) kreativitas dan critical thinking murid tidak berkembang selama pembelajaran jarak jauh; 9) murid tidak mampu meresponi berbagai informasi yang ada; 10) hanya sedikit saja murid yang meresponi pertanyaan-pertanyaan guru di dalam diskusi kelas; dan 11) murid tidak percaya diri.

Pembelajaran jarak jauh yang diterapkan di berbagai institusi pendidikan secara mendadak dan serentak dimulai pada awal tahun 2020 pada saat pandemi Covid-19. Hal ini bukan merupakan hal yang mudah bagi setiap guru dan murid untuk menjalaninya. Pernyataan ini dipertegas oleh pendapat Stefany (Stefany dkk., 2020, hlm. 216) yang mengatakan bahwa persiapan dan perencanaan kegiatan belajar mengajar daring yang tidak maksimal akan berakibat pada pengalaman belajarmengajar yang buruk bagi guru maupun murid.

Konteks pembelajaran jarak jauh seharusnya tidak mengubah hakikat dari belajar. Menurut Zendrato \& Sambonwaman, belajar artinya membawa perubahan hidup. Hidup yang tidak berfokus pada diri saja, tetapi juga memikirkan orang lain. Inilah yang menjadi tujuan pembelajaran yang holistis (Zendrato \& Sambonwaman, 2020, hlm. 625). Pembelajaran yang holistis melibatkan kepala, hati, dan tangan (Miller dkk., 2014). Kepala mengacu pada ranah kognitif, hati menyangkut ranah afektif, dan tangan melambangkan ranah psikomotor.

Yang menjadi tantangan bagi para guru adalah bagaimana ketiga ranah hidup murid tetap dapat berkembang maksimal selama pembelajaran jarak jauh. Salah satu keterampilan yang perlu dikembangkan adalah keterampilan berpikir. Ada dua kategori keterampilan berpikir yaitu LOTS dan
HOTS. LOTS atau Lower-Order Thinking Skill mencakup kemampuan menghapal, menjelaskan, dan mengaplikasikan. Sedangkan HOTS atau Higher-Order Thinking Skill meliputi kemampuan menganalisis, mengevaluasi, dan merancang (Conklin, 2011).

Supaya perubahan hidup menjadi lebih baik (transformasi) terjadi pada diri murid, pembelajaran harus direncanakan sampai kepada tahap kemampuan merancang. Pada tahap ini murid diharapkan dapat memecahkan masalahnya sendiri dan lingkungannya. Untuk menjadi problem solver, murid perlu memiliki kemampuan berpikir kritis. Kemampuan ini akan muncul saat murid diberi kesempatan untuk menganalisis, membandingkan, dan semacamnya melalui kegiatan di kelas. Bila guru memfasilitasi pemikiran kritis ini, murid akan menjadi lebih percaya diri dan tertantang di dalam berimajinasi dan menciptakan sesuatu yang baru. Inilah yang disebut kemampuan berpikir kreatif. Perpaduan kemampuan berpikir kritis dan kreatif akan berdampak pada kemampuan murid untuk memecahkan masalah yang akan membawa perbaikan pada lingkungannya (S. Johnson dkk., 2010).

Berpikir merupakan sebuah proses yang dimulai dari empati terhadap orang lain, merasa tertantang oleh situasi, berusaha menemukan jawabannya, dan membagikan pengalaman ini kepada orang lain (Cross, 2011). Di dalam tataran keterampilan berpikir, metakognisi berada pada tingkatan teratas. Metakognisi merupakan sebuah kesadaran akan pemikiran yang dimiliki, pembelajaran, dan tindakan yang membutuhkan perjuangan dan kebebasan serta berdampak pada transformasi diri (Hudson, 2019). Dengan kata lain, metakognisi melibatkan kepala, hati, dan tangan.

Di dalam piramida belajar disebutkan murid tidak hanya belajar sendiri dan mandiri, melainkan mereka dipandu untuk bersedia membagikan pendapat dan ide mereka kepada rekan sejawat. Ketika mereka mendiskusikan ide-ide mereka, berusaha untuk mewujudkannya, dan mengajarkannya kepada orang lain, pembelajaran bermakna akan terjadi (Despo dkk., 2020). Jadi pembelajaran yang bermakna adalah pembelajaran yang memberi dampak positif pada diri dan lingkungan serta meliputi seluruh ranah hidup murid. 
Para guru yang mampu memfasilitasi transformasi para murid adalah mereka yang memahami pengalaman pribadi dan profesionalnya (Cranton, 2016). Artinya, transformasi berasal dari dalam diri guru atau dimulai dari diri guru. Proses transformasi akan lebih cepat terjadi pada guru yang autentik. Ada lima pola pengembangan autentisitas yaitu: 1) memiliki kesadaran diri; 2) mengembangkan kesadaran akan keberadaan orang lain; 3) mengembangkan relasi; 4) mengembangkan kesadaran akan konteks; dan 5) mengembangkan refleksi kritis (Cranton \& Carusetta, 2004).

Berdasarkan analisis di atas, kunci meningkatnya keterampilan berpikir murid selama pembelajaran jarak jauh ada pada pengalaman transfomasi hidup guru. Oleh karena itu, pelatihan guru yang bertujuan mengajak guru berefleksi dan berkomitmen untuk membawa perbaikan pada pengajarannya terutama selama pembelajaran jarak jauh ini perlu diadakan. Harapannya para guru dapat menyadari kegiatan belajar mengajarnya selama ini dan dampaknya pada keterampilan berpikir murid, serta memikirkan metode pembelajaran yang tepat yang mampu memfasilitasi murid untuk mengalami transformasi melalui pembelajaran di ruang-ruang kelas maya (A. Johnson, 2020).

\section{METODE}

\section{Waktu dan Lokasi}

Pelatihan guru ini dilaksanakan di Sekolah Dian Harapan Jakarta yang berada di Jln. Bedugul No. 1, Daan Mogot Baru, Jakarta Barat 11840. Pelatihan ini diadakan pada 23 April 2021 dengan peserta sebanyak enam puluh delapan guru SMPSMA Sekolah Dian Harapan Jakarta. Pelatihan ini diadakan pada Jumat, pkl. 13.30-15.30.

\section{Alat dan Bahan \\ Platform yang digunakan untuk working document adalah Google, untuk mengisi angket adalah Microsoft Forms, dan pertemuan secara sinkronus adalah Microsoft Teams. Materi wajib baca diambil dari buku Online Teaching with Zoom: A Guide for Teaching and Learning with Video Conference Platforms yang ditulis oleh Aaron}

Johnson pada 2020, bab 30 Active Learning Methods. Selain itu, buku Transformative Education for the Second Renaissance oleh John. P. W. Hudson pada 2019, bab 9 Jigsaw Island Nine juga wajib baca. Suvenir berupa buku Kurikulum Bagi Pemula: Tinjaun Teori dan Aplikasi dalam Perspektif Kristiani diberikan kepada para guru yang mengisi angket, working document, dan melakukan kegiatan kelompok tercepat.

\section{Manajemen Pelaksanaan Kegiatan}

Hal-hal yang dilakukan dalam pelatihan dengan pihak sekolah antara lain: 1) mengembangkan model pelatihan dengan refleksi sebagai strategi pembelajaran; 2) menguasai konsep-konsep yang disampaikan dengan cara membaca materi yang diberikan dan menulis katakata kunci; 3) mengembangkan metode pembelajaran yang digunakan pada pelatihan yaitu kerja individu, kerja kelompok, dan diskusi dalam kelas besar; 4) menyusun refleksi dan komitmen untuk menerapkan metode pembelajaran yang dapat meningkatkan keterampilan berpikir murid; 5) menarik kesimpulan atas pelatihan yang dilakukan untuk perbaikan pelatihan ke depan baik bagi pihak fakultas dan sekolah.

Adapun langkah-langkah pelaksanaannya adalah sebagai berikut 1) melakukan analisis kebutuhan yang didasarkan pada pertemuan dengan pimpinan sekolah (bagian kurikulum) mengenai tujuan pembelajaran selama pembelajaran jarak jauh, hasil angket online yang diberikan kepada para guru, dan perencanaan pelatihan di dalam rangka memenuhi kebutuhan tersebut; 2) mengajukan permohonan kepada pimpinan fakultas sebagai tindak lanjut dari surat permohonan pelatihan guru yang diajukan oleh pihak sekolah; 3) mengadakan komunikasi intensif dengan pimpinan sekolah (bagian kurikulum) mengenai detail pelaksanaan pelatihan guru yang meliputi metode pelatihan, materi pelatihan, dan jadwal serta rundown pelaksanaan pelatihan; 4) mengadakan pertemuan intensif dengan tim PKM yaitu 2 mahasiswa PGSD tahun pertama untuk membahas link-link yang akan diberikan kepada para peserta sebelum dan sesudah pelatihan, pengolahan data, pembagian kelompok, pembagian tugas sebelum, saat, dan sesudah pelatihan; 5) merekap angket yang 
diberikan sebelum pelatihan; 6) memberikan link evaluasi pelatihan; 7) mendokumentasikan foto kegiatan pelatihan; 8) mengirimkan semua hasil pekerjaan para guru baik secara individu atau kelompok dan kesimpulan pelatihan kepada pihak sekolah untuk merancang ide kelanjutan dari pelatihan ini.

Tabel 1. Rundown kegiatan pelatihan Jumat, 23 April 2021, 13.30-15.30 WIB (120 menit)

\begin{tabular}{|c|c|c|}
\hline Waktu & Kegiatan & PIC \\
\hline $10^{\prime}$ & $\begin{array}{l}\text { Pendahuluan, perkenalan, } \\
\text { dan penyampaian tujuan } \\
\text { serta sistem belajar di } \\
\text { pelatihan guru }\end{array}$ & $\begin{array}{l}\text { Pimpinan } \\
\text { Sekolah } \\
\text { (kurikulum) }\end{array}$ \\
\hline $10^{\prime}$ & $\begin{array}{l}\text { Penjelasan tentang } \\
\text { pendidikan yang holistis. } \\
\text { Survei dengan } \\
\text { mentimeter: heart, head, } \\
\text { and hand. }\end{array}$ & Pembicara \\
\hline $10^{\prime}$ & $\begin{array}{l}\text { Review taksonomi Bloom } \\
\text { (afeksi, psikomotor, dan } \\
\text { kognitif) } \\
\text { Survei dengan } \\
\text { mentimeter: mastery level. }\end{array}$ & Pembicara \\
\hline $10^{\prime}$ & $\begin{array}{l}\text { Sharing hasil angket } \\
\text { keterampilan berpikir } \\
\text { yang dikumpulkan melalui } \\
\text { Ms Forms. }\end{array}$ & Pembicara \\
\hline $10^{\prime}$ & $\begin{array}{l}\text { Penjelasan tentang } \\
\text { keterampilan berpikir } \\
\text { yang dihubungkan dengan } \\
\text { Visi Misi sekolah. }\end{array}$ & Pembicara \\
\hline $155^{\prime}$ & $\begin{array}{l}\text { Sharing di kelompok } \\
\text { tentang pengalaman } \\
\text { penerapan salah satu } \\
\text { metode belajar yang ada } \\
\text { di bab } 30 \text { Active Learning } \\
\text { Methods. }\end{array}$ & Kelompok \\
\hline $25^{\prime}$ & $\begin{array}{l}\text { Kerja kelompok dengan } \\
\text { metode Parley- Précis- } \\
\text { Post dalam menyusun } 1 \\
\text { kalimat pemahaman } \\
\text { tentang keterampilan } \\
\text { berpikir. }\end{array}$ & Kelompok \\
\hline $10^{\prime}$ & Penjelasan tentang guru & Pembicara \\
\hline
\end{tabular}

\begin{tabular}{|c|l|l|}
\hline & $\begin{array}{l}\text { yang membawa } \\
\text { transformasi pada hidup } \\
\text { murid. }\end{array}$ & \\
\hline 10 & $\begin{array}{l}\text { Setiap peserta menulis } \\
\text { komitmen untuk } \\
\text { membawa dampak } \\
\text { transformasi pada hidup } \\
\text { murid sebagai bentuk } \\
\text { refleksi. }\end{array}$ & Pembicara \\
\hline 10 & $\begin{array}{l}\text { Penutup dan mengisi link } \\
\text { evaluasi pelatihan }\end{array}$ & $\begin{array}{l}\text { Pimpinan } \\
\text { Sekolah } \\
\text { (kurikulum) }\end{array}$ \\
\hline
\end{tabular}

\section{Pelaksanaan}

Pelatihan ini dilaksanakan pada Jumat, 23 April 2021 selama 120 menit di jam professional development guru yang sudah dialokasikan setiap minggunya. Pelatihan ini diikuti oleh guru termasuk para pimpinan sekolah sebanyak 68 orang, 1 pembicara, dan 2 mahasiswa asisten. Kegiatan pertama adalah Pendahuluan, perkenalan, dan penyampaian tujuan serta sistem belajar di pelatihan guru ini.

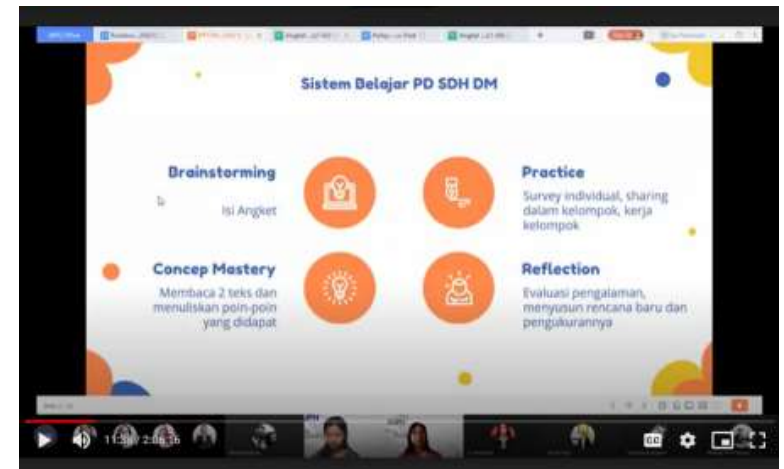

Gambar 1. Sistem Pelatihan

Selanjutnya, pembicara memberikan penjelasan tentang pendidikan yang holistis dan diikuti dengan mengisi survei menggunakan mentimeter: heart, head, and hand yang bertujuan mendapat gambaran ranah hidup murid yang paling menjadi fokus untuk diringkatkan selama ini. 


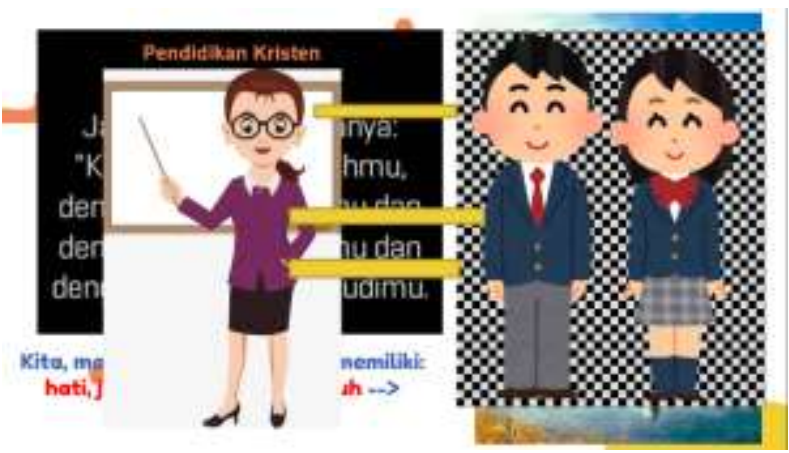

Gambar 2. Pendidikan Holistis

Kemudian, pembicara mengulas taksonomi Bloom (ranah afeksi, psikomotor, dan kognitif) dan diikuti dengan pemberian survei menggunakan mentimeter: mastery level yang bertujuan untuk melihat kesenjangan antara harapan dan realita guru di dalam meningkatkan keterampilan berpikir murid.
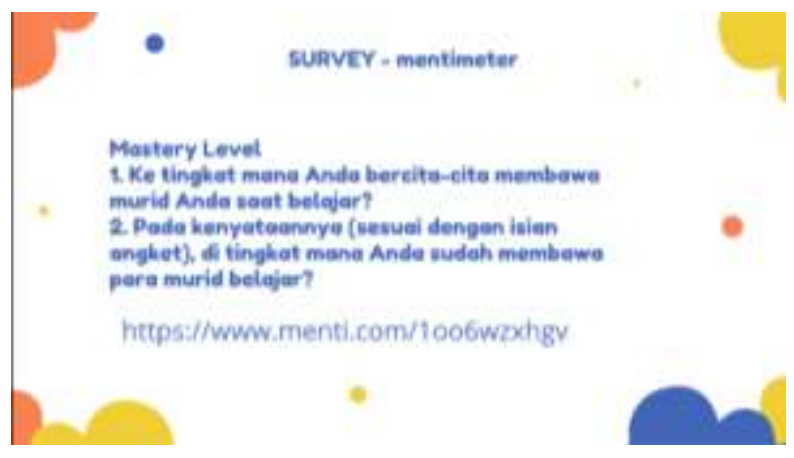

Gambar 3. Survei Mastery Level

Langkah berikutnya, pembicara menyimpulkan hasil angket keterampilan berpikir yang dikumpulkan melalui Microsoft Forms seminggu sebelum pelatihan yang meliputi apa yang mereka ketahui tentang keterampilan berpikir, mengapa keterampilan ini penting untuk ditingkatkan, dan bagaimana cara meningkatkannya. Hasil ini dibahas dan dihubungkan dengan Visi Misi sekolah.

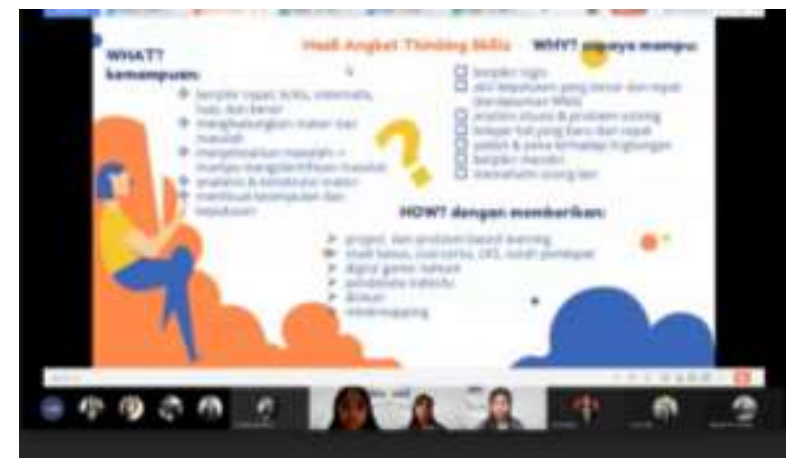

\section{Gambar 4. Survei Thinking Skill}

Pembicara melanjutkan penjelasan tentang proses berpikir yang meliputi empat tahap yaitu empati, tantangan, penemuan, dan sharing. Setelah itu, para peserta masuk dalam kelompok kecil dan saling berbagi pengalaman mengenai penerapan salah satu metode belajar yang ada di bab 30 Active Learning Methods.

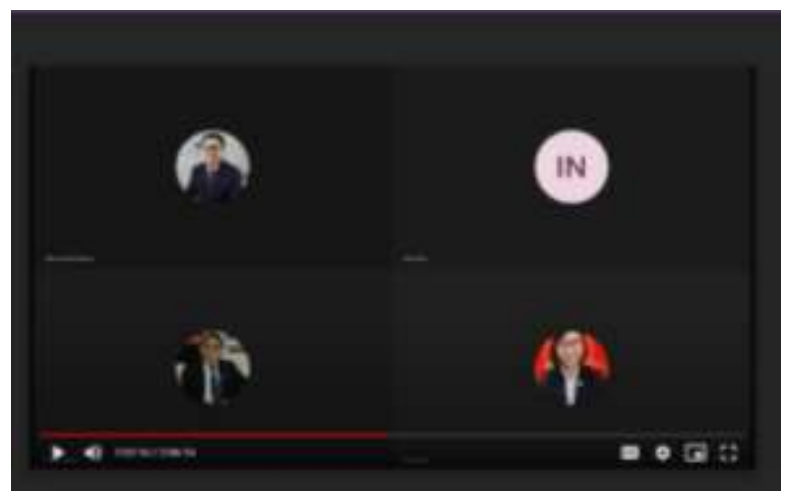

Gambar 5. Sharing Kelompok

Setelah penjelasan tentang metakognisi oleh pembicara, peserta kembali masuk ke dalam kelompok dan bekerja dengan metode ParleyPrécis-Post untuk menyusun 1 kalimat pemahaman tentang keterampilan berpikir berdasarkan tiap kata kunci yang sudah dipilih oleh para peserta berdasarkan membaca atau diskusi.

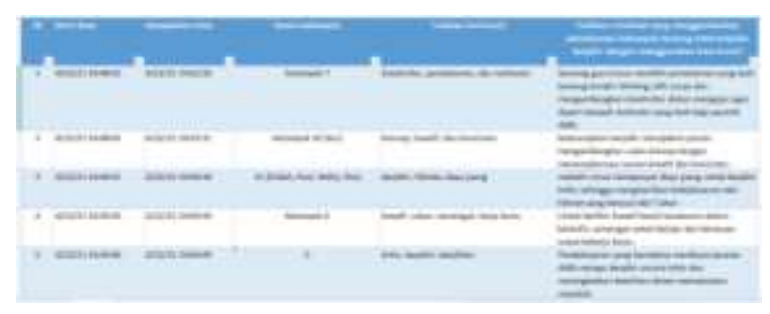

Gambar 6. Metode Parley-Précis-Post

Pembicara memberikan penjelasan tentang guru yang membawa transformasi pada hidup murid. Setiap peserta menulis komitmen bagaimana membawa dampak transformasi pada hidup murid sebagai bentuk refleksi. Peserta juga menyebutkan salah satu metode pembelajaran yang akan diterapkan selama pembelajaran jarak jauh dan

$$
\text { Pendidikan } 768
$$


memilih accountable partner yang akan memberikan dorongan dan umpan balik supaya peserta selalu bertumbuh menjadi guru yang lebih baik hari demi dari.

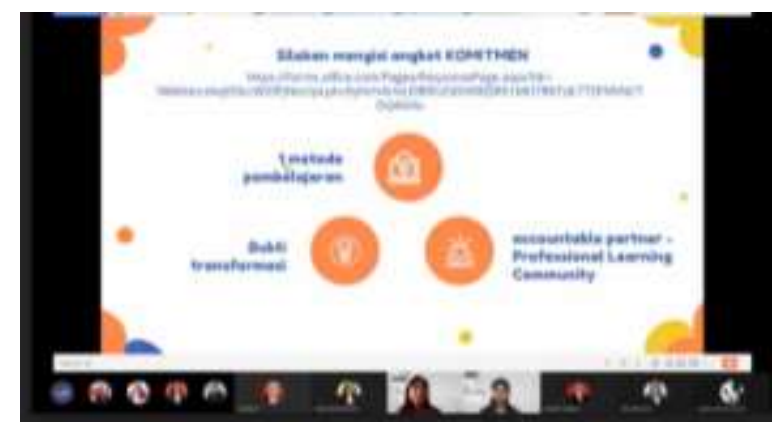

Gambar 7. Angket Komitmen

Sebelum penutup, para peserta mengisi link evaluasi pelatihan yang berisi motivasi belajar peserta, kegiatan pelatihan yang bernuansa dinamis, kegiatan yang paling membuat peserta merasa terlibat, dan kelebihan pembicara. Seluruh hasil angket dikirimkan kepada pihak sekolah untuk perbaikan ke depan dalam hal perencanaan dan pelaksanaan pelatihan guru.

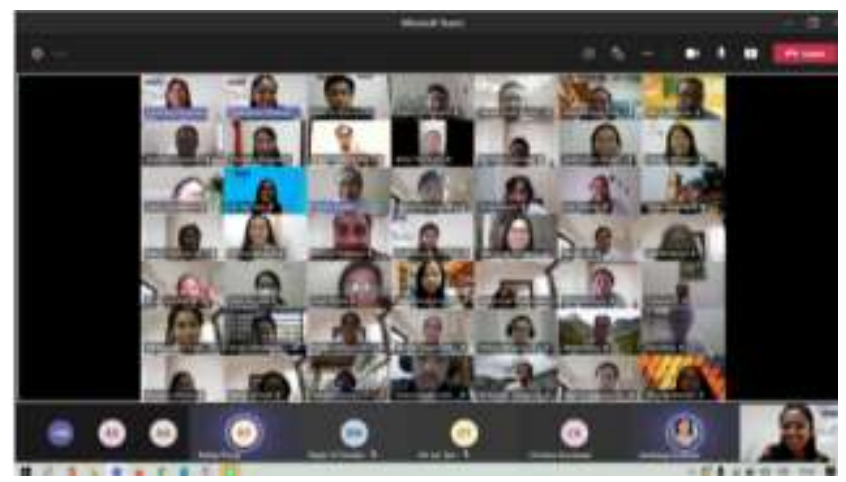

Gambar 8. Foto Bersama

\section{HASIL DAN PEMBAHASAN}

Seminggu sebelum pelaksanaan pelatihan, pembicara memberikan angket yang bertujuan memperoleh gambaran mengenai pemahaman dan arti penting keterampilan berpikir serta cara untuk meningkatkan keterampilan berpikir murid.
Tabel 2. Angket Keterampilan Berpikir

\begin{tabular}{|c|c|}
\hline No. & Pertanyaan \\
\hline 1 & $\begin{array}{l}\text { Berdasarkan pengalaman mengajar selama } \\
\text { tahun akademik 2020-2021 ini (tidak perlu } \\
\text { berdasarkan teori buku/artikel - murni } \\
\text { pengalaman sendiri), apa yang Bapak/Ibu } \\
\text { temui/ketahui dari para murid tentang } \\
\text { keterampilan berpikir/thinking skills? } \\
\text { Tuliskan dalam 1-3 kalimat! }\end{array}$ \\
\hline 2 & $\begin{array}{l}\text { Berdasarkan pengalaman Bapak/Ibu } \\
\text { mengajar selama tahun akademik 2020- } \\
2021 \text { ini, apa pentingnya keterampilan } \\
\text { berpikir/thinking skills bagi murid kita? }\end{array}$ \\
\hline 3 & $\begin{array}{l}\text { Bagaimana cara meningkatkan } \\
\text { keterampilan berpikir/thinking skills di } \\
\text { kelas Bapak/Ibu selama online } \\
\text { learning/Home-Based Learning di tahun } \\
\text { akademik 2020-2021 ini? Sebutkan } \\
\text { minimal 1 contoh nyata dari kegiatan di } \\
\text { kelas Bapak/Ibu! Tuliskan dalam 1-3 } \\
\text { kalimat! }\end{array}$ \\
\hline
\end{tabular}

Secara rata-rata jawaban peserta atas pertanyaan 1 yang menanyakan tentang what/kemampuan berpikir adalah 1) kemampuan berpikir cepat, kritis, sistematis, luas, dan benar; 2) kemampuan menghubungkan materi dan masalah; 3) kemampuan menyelesaikan masalah dan mengidentifikasi masalah; 4) kemampuan menganalisis dan mengkonstruksi materi; dan 5) kemampuan membuat kesimpulan dan mengambil keputusan.

Secara rata-rata jawaban peserta atas pertanyaan 2 yang menanyakan tentang why/tujuan memiliki keterampilan berpikir adalah supaya murid mampu 1) berpikir logis; 2) mengambil keputusan yang benar dan tepat (berdasarkan Wawasan Kristen Alkitabiah); 3) menganalisis situasi dan memecahkan masalah; 4) belajar hal yang baru dan cepat; 5) peduli dan peka terhadap lingkungan; 6) berpikir mandiri; dan 7) memahami orang lain.

Secara rata-rata jawaban peserta atas pertanyaan 3 yang menanyakan tentang how/cara meningkatkan keterampilan berpikir murid adalah dengan menerapkan 1) project dan problem based learning; 2) studi kasus; 3) soal cerita; 4) LKS; 5) curah pendapat; 6) digital game seperti kahoot; 7) 
pendekatan individu; 8) diskusi; dan 9) mindmapping.

Setelah mendengarkan paparan tentang pendidikan Kristen yang melibatkan hati, jiwa, akal budi, dan tubuh atau yang sering disebut pendidikan yang holistis, peserta mengisi survei head, heart, and hand melalui mentimeter yang berisi tentang ranah hidup murid yang paling sering menjadi fokus guru selama mengajar.

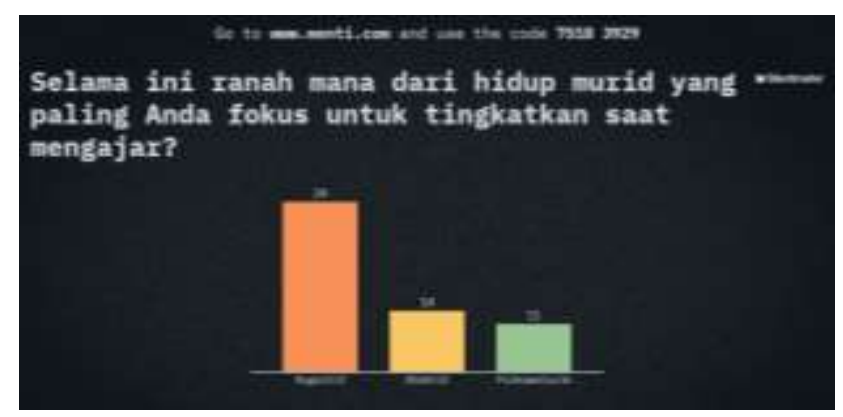

Gambar 9. Ranah Hidup Murid

Hasil survei menunjukkan $61 \%$ (39 peserta) fokus pada peningkatan ranah kognitif, 22\% (14 peserta) fokus pada peningkatan ranah afektif, 17\% (11 peserta) fokus pada peningkatan ranah psikomotorik.

Setelah mendengarkan paparan tentang tingkatan kognitif, afektif, dan psikomotor, survei tentang mastery level diberikan.

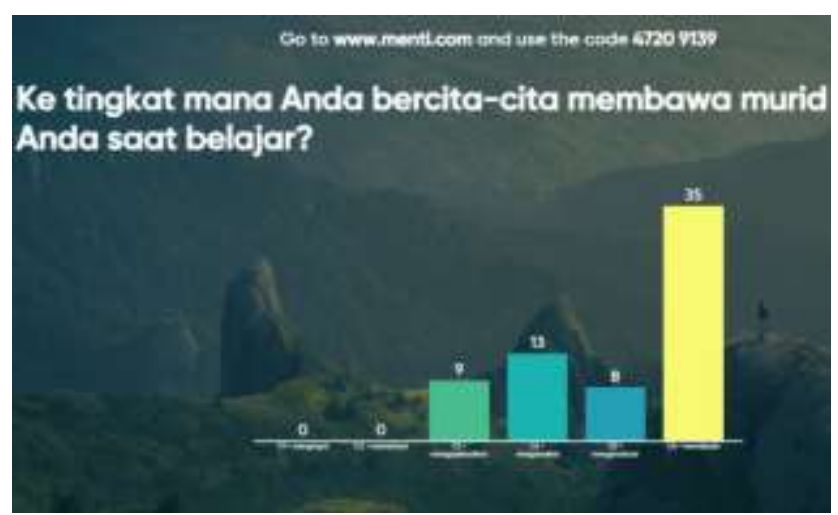

Gambar 10. Harapan Guru

Hasil survei menunjukkan 14\% (9 peserta)

Poda kenyataannya (sesual dengan isian angket), di tingkat mana Anda sudah membawa para murid belajar? bercita-cita membawa murid ke level aplikasi, 20\% (13 peserta) ke level analisis, 12\% (8 peserta) ke level evaluasi, 54\% (35 peserta) level merancang.

\section{Gambar 11. Realita Pengajaran}

Hasil survei tentang harapan dibandingkan dengan realita yang dialami peserta saat mengajar. Realita menunjukkan bahwa $1 \%$ (1 peserta) sudah membawa murid ke level mengingat, $13 \%$ (7 peserta) ke level memahami, 32\% (17 peserta) ke level mengaplikasikan, 33\% (18 peserta) ke level menganalisis, $10 \% \quad(5$ peserta $)$ ke level mengevaluasi, $11 \%$ (6 peserta) ke level merancang.

Setelah sharing kepada teman kelompok 1 metode yang sudah pernah diterapkan, kelebihan, kesulitan, dan dampak penerapan metode ini pada murid/kelas selama $H B L$ berdasarkan bab 30 Active Learning Methods oleh Johnson, peserta mendengarkan paparan tentang metakognisi yang menyangkut head, hand, and heart yang memiliki implikasi transformasi diri dan menyangkut kebebasan dalam belajar (Hudson, 2019, hlm. 95).

Kemudian, peserta kembali berada di kelompok untuk menyusun pemahaman mereka tentang keterampilan berpikir berdasarkan diskusi tentang pendidikan Kristen yang holistis, 3 ranah dan tingkatannya, pembelajaran yang bermakna, dan metakognisi. Hasil diskusi kelompok adalah sebagai berikut: 1) guru perlu mengembangkan kreativitas mengajar untuk meningkatkan keterampilan berpikir murid; 2) guru perlu melatih daya juang murid untuk berpikir kritis; 3) pembelajaran yang bermakna mampu membuat murid berpikir kritis dan membuat keputusan; 4) guru dan murid mau berproses untuk merangsang keterampilan berpikir; 5) guru perlu memiliki perencanaan yang baik untuk melatih keterampilan berpikir murid; 6) kepedulian guru terhadap kondisi psikologis murid yang tercermin dari pemilihan metode belajar dapat merangsang kreativitas berpikir murid; 7) guru perlu mengalami transformasi terlebih dahulu supaya membawa dampak pada pendidikan yang holistis.

Peserta mendengar pemaparan tentang proses transformasi dalam diri murid yang 
dipengaruhi oleh pribadi guru yang autentik. Ada lima langkah pengembangan autentisitas yang dijabarkan juga (Cranton \& Carusetta, 2004). Setelah itu, peserta diberi waktu untuk merefleksikan apa yang sudah dibaca dan didiskusikan. Fokus refleksi yaitu 1) menuliskan 1 metode pembelajaran yang akan diterapkan selama pembelajaran jarak jauh yang dapat meningkatkan keterampilan berpikir kritis; 2) menentukan indikator yang dapat memfasilitasi murid mengalami transformasi; dan 3) menentukan accountable partner yang akan selalu memberi umpan balik atas komitmen dan penerapan metode pembelajaran supaya selalu bertumbuh sebagai pendidik kristiani.

Hasil refleksi 1 yaitu metode pembelajaran yang akan diterapkan diantaranya adalah journaling, think-pair-share, jigsaw, drama/roleplay, refleksi, discovery learning, problem based learning, wawancara, diskusi kelompok, studi kasus, concept mapping, dan peer teaching. Hasil refleksi 2 yaitu indikator fasilitasi transformasi diantaranya adalah murid mampu berpikir kritis, dapat berkolaborasi dengan rekanrekannya, berpikir dan berbicara secara sistematis, bersikap terbuka dan percaya diri, menjadi pendengar yang baik, mampu mengekspresikan pendapat, peka terhadap diri, 4C (critical thinking, communicating, collaborating, creativity) dan empati, menghargai pendapat orang lain, mampu menemukan solusi atas permasalahan sehari-hari, perubahan perilaku. Hasil refleksi 3 tentang accountable partner, para peserta memilih sesama rekan guru, team leader, kepala sekolah atau wakilnya.

Berdasarkan evaluasi pelatihan, 1) peserta termotivasi untuk merancang pembelajaran yang dapat meningkatkan keterampilan berpikir; 2) peserta membutuhkan pelatihan lanjutan yang membahas masalah-masalah yang lebih detail sehubungan dengan pembelajaran jarak jauh; 3) seluruh kegiatan yang diberikan selama pelatihan membuat para peserta merasa terlibat; 4) para peserta mengapresiasi pembicara dalam hal interaksi, pemilihan materi dan kegiatan, serta cara penyampaian).

\section{KESIMPULAN}

Dari pelaksanaan pelatihan di Sekolah Dian Harapan Jakarta ini dapat disimpulkan bahwa para peserta memahami arti keterampilan berpikir dan pentingnya keterampilan berpikir murid ditingkatkan, serta bagaimana meningkatkannya dalam konteks pembelajaran jarak jauh.

Para peserta juga mampu memilih metode pembelajaran yang dapat diterapkan untuk pembelajaran jarak jauh yang dapat meningkatkan keterampilan murid dan menentukan accountable partner yang akan mendorong mereka untuk menjadi guru yang lebih baik.

Pelatihan ini secara umum membangun motivasi para guru untuk meningkatkan keterampilan mengajar selama pembelajaran jarak jauh, maka pelatihan ini dapat diteruskan dengan topik-topik yang lebih detail untuk membahas berbagai masalah murid yang muncul selama pembelajaran jarak jauh.

\section{UCAPAN TERIMAKASIH}

Ucapan terimakasih disampaikan kepada Teachers College, Universitas Pelita Harapan yang telah memberikan izin kepada penulis untuk menjadi pembicara Professional Development di Sekolah Dian Harapan Jakarta.

\section{REFERENSI}

Conklin, W. (2011). Higher-Order Thinking Skills to Develop 21st Century Learners. Shell Education.

Cranton, P. (2016). Understanding and Promoting Transformative Learning: A Guide to Theory and Practice. Stylus Publishing, LLC.

Cranton, P., \& Carusetta, E. (2004). Developing Authenticity as a Transformative Process. Journal of Transformative Education, 2(4), 276-293.

https://doi.org/10.1177/1541344604267898

Cross, N. (2011). Design Thinking: Understanding How Designers Think and Work. Berg.

Despo, K., Elli, D., \& Nikleia, E. (2020). Fostering Meaningful Learning Experiences Through Student Engagement. IGI Global. 
Hudson, J. P. W. (2019). Transformative Education for the Second Renaissance. IAP.

Johnson, A. (2020). Online Teaching with Zoom: A Guide for Teaching and Learning with Videoconference Platforms. Aaron Johnson.

Johnson, S., Siegel, H., \& Winch, C. (2010). Teaching Thinking Skills. A\&C Black.

Miller, J. P., Irwin, M., \& Nigh, K. (2014). Teaching from the Thinking Heart: The Practice of Holistic Education. IAP.

Stefany, S., Purbojo, R., \& Adeline, C. (2020). DIGITAL LITERACY: ONLINE CLASS MANAGERIAL FOR EDUCATORS. Jurnal Sinergitas PKM \& CSR, 4(3), 215225.

https://doi.org/10.19166/jspc.v4i3.2805

Zendrato, J., \& Sambonwaman, M. N. (2020). Dampak Pengiring Proyek Video Pembelajaran Pada Matakuliah Studi Kurikulum di Program Studi Pendidikan Guru Sekolah Dasar Universitas Pelita Harapan. Jurnal Basicedu, 4(3), 624-636. https://doi.org/10.31004/basicedu.v4i3.412 